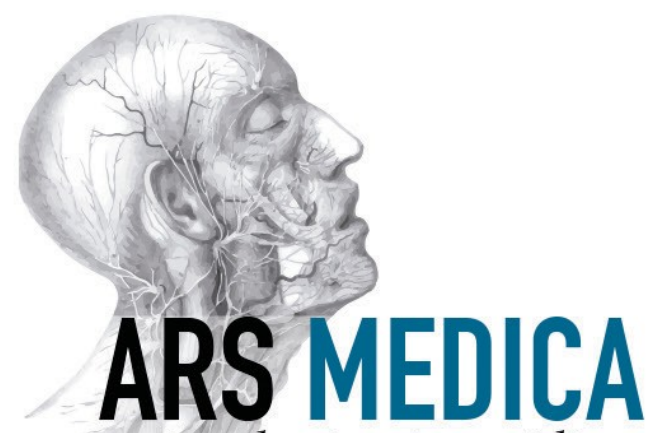

revista de ciencias médicas

Volúmen 38, número 1, año 2009

El presente artículo corresponde a un archivo originalmente publicado en Ars Medica, revista de estudios médicos humanísticos, actualmente incluido en el historial de Ars Medica Revista de ciencias médicas. El contenido del presente artículo, no necesariamente representa la actual línea editorial. Para mayor información visitar el siguiente vínculo: http://www.arsmedica.cl/index.php/MED/about/submissions\#authorGuidelines 


\title{
Aborto y embrión en pre-singamia
}

\author{
Juan de Dios Vial Correa \\ Profesor Titular \\ Facultad de Ciencias Biológicas \\ Pontificia Universidad Católica de Chile
}

\section{Resumen}

El artículo refiere brevemente el desarrollo del embrión antes de la primera división de segmentación. Penetrado el espermio en el oocito, de inmediato empiezan fenómenos de interacción entre componentes materno y paterno. Por lo tanto, el desarrollo del zigoto antes de la primera división de segmentación ya tiene características temporales y espaciales de un organismo de la especie humana.

Por todo esto, el autor afirma que querer eliminar la palabra "aborto" de la interferencia con la vida en esta etapa del desarrollo no tiene ninguna base en los hechos científicos ni en su valoración ética, y se limita a dejar ver una preferencia de lenguaje.

palabras clave: aborto; zigoto; embrión; bioética.

\section{ABORTION AND EMBRYO IN PRE-SYNGAMIC PERIOD}

This article deals with the development of the embryo before the first segmentation division. Once the sperm enters the oocyte, the interaction of paternal and maternal elements begins, following the patterns proper to the human species.

The elimination of the word "abortion" when referring to interference with the life of the embryo at this stage can find no support in scientific evidence.

Key words: abortion; zygote; embryo; bioethics.

El tema del aborto en las etapas de desarrollo previas a la implantación del embrión ha sido objeto de mucha discusión en tiempos recientes. Hay un fuerte interés en establecer que el embarazo comienza con la implantación, de modo que maniobras dirigidas contra el embrión aún no implantado no deben ser tenidas como abortivas aunque ellas rematen en la muerte del embrión.

Esta postura ha sido apoyada en publicaciones de organismos internacionales, y ha sido recibida con beneplácito en muchos círculos 
de personas interesadas en actuar sobre la procreación. Recientemente ella se agitó en torno a la acción de la "píldora del día después", cuando se sostenía que una acción que impidiera la implantación del embrión recién fecundado no podría ser calificada como aborto.

Veremos inmediatamente que el zigoto es una etapa en el desarrollo de un organismo, y que por lo tanto su destrucción equivale a darle muerte a éste. La discusión que se suscitó gira en torno a una mera cuestión de lenguaje: desde algún punto de vista parecería impropio llamar "aborto" a una acción que destruye un organismo que no tiene todavía un "sitio" propio, que no está comprometido en una "preñez".

Este trabajo pretende recordar brevemente que la existencia de un organismo humano empieza con la penetración del óvulo por el espermatozoide en la fertilización, y que el desarrollo se hace en varias etapas sucesivas, una de las cuales es justamente el tránsito por la trompa hasta llegar a la implantación en el útero. Entre el embrión implantado y sus etapas previas no hay más diferencia que la que muestran algunos organismos entre las etapas de vida libre y la vida sésil.

Creo que la razón de fondo de esta discusión es que las expresiones "aborto", "abortivas" inspiran un fuerte rechazo de gran parte del público, y se busca entonces convencer a éste de que hay una parte de la vida embrionaria con la cual se puede interferir sin que estas maniobras puedan caer comprendidas bajo esas denominaciones.

Como una contribución muy modesta al tema de conjunto quisiera recordar qué cosa es un zigoto, desde el punto de vista biológico.

El zigoto es una célula que se genera por la fusión de los gametos. Como tal, dura hasta la primera división de segmentación.

Un resumen muy somero de lo ocurrido entre la penetración del espermio y la primera división arroja los siguientes elementos ${ }^{1}$ :

Inmediatamente después de penetrado el espermio se producen eventos que bloquean la poliespermia. Son cambios electroquímicos en la membrana, exocitosis de los gránulos corticales y el término de la segunda división de maduración del oocito. En esta forma se constituye el zigoto, célula protegida contra la penetración de nuevos espermatozoides.

La cabeza espermática que ha quedado incorporada al espacio interno del zigoto sufre cambios importantes en sus componentes. $\mathrm{Su}$ envoltura nuclear se desintegra y la cromatina se descondensa como 
expresión visible de cambios bioquímicos cuales son la reducción de grupos disulfuro de las protaminas (proteínas del ADN de la cabeza espermática), y el reemplazo de ellas por histonas, proteínas de origenovular. Mientras esto ocurre la cromatina ovular pasa a interfase. A continuación se desarrolla la envoltura nuclear en torno a la cromatina de origen espermático y a la de origen ovular. Así se forman dos estructuras con aspecto de núcleos, los llamados pro núcleos. La síntesis de ADN empieza entre 8 y 14 horas después de constituidos los pro núcleos. Este proceso requiere la colaboración de proteínas citoplasmáticas mayormente de origen ovular.

Estos cambios han llevado a la constitución de los dos pro núcleos, convencionalmente llamados masculino y femenino. Esta denominación ignora el hecho de que en el pro núcleo masculino la mayor parte de sus componentes (con la fundamental excepción de la mitad de su ADN) es de origen ovular. El proceso hasta aquí es claramente una línea de desarrollo continua en la que intervienen cooperativamente biomoléculas de origen espermático y de origen ovular.

Los pro núcleos se ubican luego hacia el centro del zigoto, y los centríolos se colocan hacia los polos. Hay que hacer notar que dichos centríolos provienen exclusivamente del espermio.

Un momento después se producirá la aparente fusión de los pro núcleos("singamia").

Lo que hemos visto es un proceso ordenado y continuo que comienza con la entrada del espermio y culmina en la "singamia". Los varios componentes químicos del óvulo y del espermio se incorporan coordinadamente a este proceso. Es obvio que desde su inicio éste se halla determinado a madurar en un embrión, y que esta maduración es mucho más exacta que si fuera meramente específica: toda la efectividad de la fecundación "in vitro" se halla ligada a que el proceso descrito dependa de dos progenitores y esté encaminado hacia la expresión final de un individuo único en la especie humana. De manera perfectamente legítima se puede decir que el desarrollo del embrión ha comenzado con la penetración del óvulo por el espermio y sigue luego ordenadamente pasando por etapas sucesivas.

Conviene entonces hacer alguna precisión que no sea enteramente una constatación empírica, y decir que lo que hemos descrito es el comienzo del desarrollo de un organismo de la especie humana.

Cualquier "organismo" tiene al menos dos rasgos fundamentales: 
1) Él sigue en su vida un camino o trayectoria de desarrollo que puede ser predicho con razonable exactitud, y ese trayecto se va regulando contra perturbaciones externas (trayectoria "robusta"). Esto se verifica en la vida del zigoto.

2) La evolución de estos caminos de desarrollo tiene lugar dentro de un espacio físicamente delimitado (en nuestro caso, el interior del zigoto). Es distinto hablar del desarrollo de un organismo que del de una población o una especie.

En la etapa presingámica el embrión se modifica con una mínima contribución del genoma, el cual está silente durante este período, aunque no lo esté por completo. Así por ejemplo, Ao y Cols ${ }^{2}$ han demostrado la presencia de transcriptos de ZFY, gene del cromosoma Y paterno.

No es requisito para hablar de "organismo" el que su genoma esté globalmente activado. Por el contrario, los organismos atraviesan por períodos en los cuales los fenómenos de transcripción y traducción del genoma son muy reducidos aunque no están ausentes.

A este propósito, es interesante notar que ya en el curso del desarrollo del zigoto se registra una interacción entre la cromatina de los pro núcleos y proteínas de origen ovular (materno). Así el factor de transcripción T1F1alfa se transloca hacia los pro núcleos. Su ablación experimental impide la regulación de genes que son esenciales para el desarrollo precoz ${ }^{3}$. Así se ve que también las primeras manifestaciones funcionales del genoma tienen lugar por una interacción de los componentes de origen materno y paterno.

Entonces la destrucción de un embrión en etapa presingámica es la destrucción de un organismo humano, con toda la carga moral negativa que semejante acción conlleva.

\section{Citas}

${ }^{1}$ Vial J. de D., Dabike M., The embryo as an organism. Proceedings of Third Assembly of the Pontifical Academy for life. Juan de Dios Vial Correa and Elio Sgreccia eds. Libreria Editrice Vaticana, 1998, pág. 317-33. 
${ }^{2}$ Ago Asangla R.P., Robert E., Winston M.L., Handyside A.H. Transcription of paternal Y-linked genes in the human zygote as early as the pronucleate stage. Zygote 2 (November), 1994; pág. 281-287.

${ }^{3}$ Torres-Padilla, M. E., Zernicka-Goetz M. Role of T1F1 as a modulator of embryonic transcription in the mouse zygote. Journal of Cell Biology. July 31; 174 (3):329-338, 2006. 